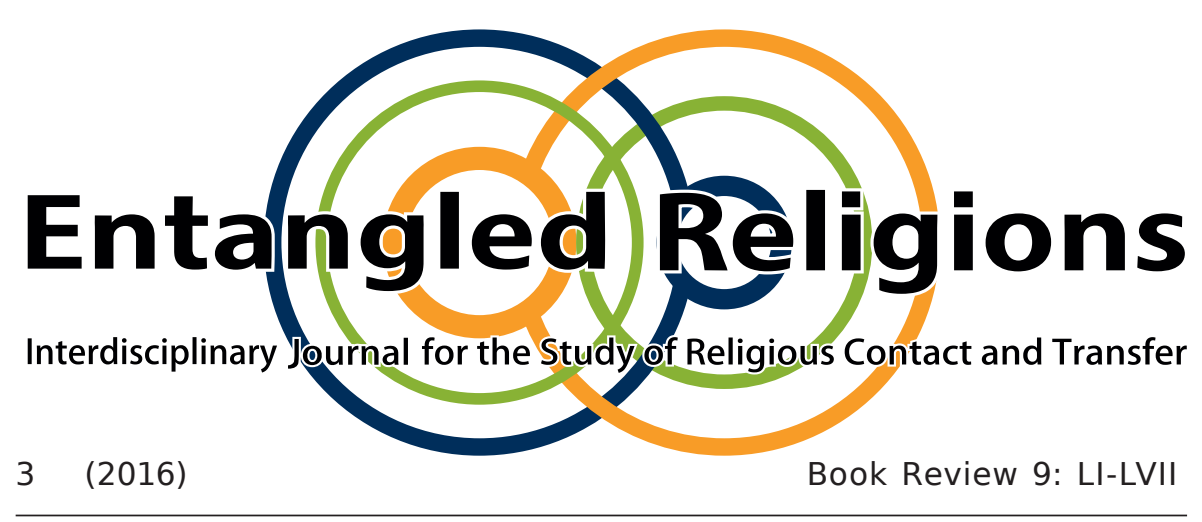

Mani at the Court of the Persian Kings:

Studies on the Chester Beatty Kephalaia Codex

Nag Hammadi and Manichaean Studies, v. 87. Leiden:

Brill, 2015. $320+x$ pages, €110.00, ISBN: 9789004234703

IAN GARDNER, JASON BEDUHN, PAUL DILLEY

(C) 2016 Ruhr-Universität Bochum

Entangled Religions 3 (2016)

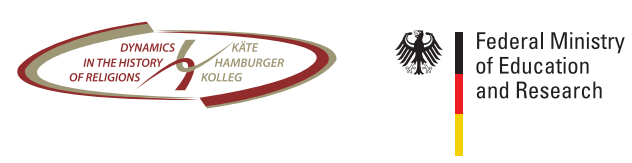




\section{Mani at the Court of the Persian Kings: Studies on the Chester Beatty Kephalaia Codex}

Nag Hammadi and Manichaean Studies, v. 87. Leiden: Brill, 2015. $320+x$ pages, $€ 110.00$, ISBN: 9789004234703

IAN GARDNER, JASON BEDUHN, PAUL DILLEY

Mani at the Court of the Persian Kings is a volume of promises and high expectations for the study of Manichaeism. Its three authors, Gardner, BeDuhn, and Dilley, explore the promises of a 'new' Manichean text, the fourth-fifth century Coptic codex of Chapters of the Wisdom of My Lord Manichaios, discovered eight decades ago in Egypt, and brought to the Dublin Chester Beatty Library after World War II. Due to its fragmentary state and poor preservation, however, the editing process of this text did not move past the 1986 facsimile stage. ${ }^{1}$ The present volume documents the authors' endeavor of making preliminary historical and literary sense of the Chester Beatty Kephalaia while working on its critical edition and English translation. The team of scholars already established that the Chester Beatty Kephalaia (henceforth $2 \mathrm{Ke}$ ) is different from the Berlin Kephalaia (the Chapters of the Teacher, henceforth $1 \mathrm{Ke}$ ), discovered at the

1 Søren Giversen, Rodolphe Kasser, and Martin Krause, The Manichaean Coptic Papyri in the Chester Beatty Library; Cahiers d'orientalisme, vols. $14-17$ (Geneva: P. Cramer, 1986). Gardner, BeDuhn, and Dilley announced that the final critical edition of the Chester Beatty Kephalaia will have a different page order than its 1986 facsimile reproduction. 
same time, but already edited and translated into English, regarding both of them as parts of the same diptych, opened by the Berlin codex. ${ }^{2}$

The volume includes nine chapters structured into three distinct sections. The first part contains three studies on the content of $2 \mathrm{Ke}$; the second explores new sources made available through the Chester Beatty Codex; finally, the last section of the volume places Manichaeism within the larger context of the history of ancient religions. In the "Introduction" (pp. 1-12), Gardner reviews the challenges this team encountered in working on a very fragmented manuscript. Using modern techniques for digitallyenhanced imaging, the team went beyond the information provided by the, often, illegible 1986 facsimile edition, and produced the first draft of the edition of $2 \mathrm{Ke}$ in 2014. The present volume reads both like an “interim report on the project's progress" (p. 76n4) but also like a coherent collection of essays on the Persian setting of Mani and his first disciples, as well as on the spread of Manichaeism in Asia and Europe in its first two centuries of existence.

In his discussion of the genre and context of Chester Beatty Kephalaia (pp. 15-51), Dilley argues that 2 Ke presents Mani's debates with other religious or philosophical figures in the agonistic environment cultivated by Persian kings at the Sasanian court. The style itself of the debates, articulated through the dialogical structure of questions-and-answers, maintains Dilley, echoes quite well the Greek genre of erotapokriseis,

2 Hugo Ibscher (ed), Kephalaia, Band I, 1. Hälfte (Lieferung 1-10); Manichäische Handschriften der staatlichen Museen Berlin (Stuttgart: W. Kohlhammer, 1940); Alexander Böhlig (ed.), Kephalaia, Band I, 2. Hälfte; Manichäische Handschriften der staatlichen Museen Berlin (Stuttgart: W. Kohlhammer, 1966); Wolf-Peter Funk (ed.), Manichäische Handschriften der staatlichen Museen Berlin: 1 Hälfte 2, Lieferung 13-14 (Stuttgart: Kohlhammer, 1999); Wolf-Peter Funk (ed.), Manichäische Handschriften der staatlichen Museen Berlin: 1,2, [3]. Lieferung 15-16 (Stuttgart: Kohlhammer, 2000); lain Gardner, The Kephalaia of the Teacher: The edited Coptic Manichaean Texts in Translation with Commentary (Leiden: E.J. Brill, 1995). 
and Iranian and Buddhist similar literary practices. Searching for reliable sources for the history of the first Manichaean generations and the institutionalization of Manichaean Church, BeDuhn finds, in the next chapter (pp. 52-74), a more complicated story of Manichaean missionary travels both in the Roman Empire and throughout Central Asia. His scenario entails a nuanced narrative in which missionaries returning to the center of Sasanian Manichaean authority reworked Mani's initial religious message according to recent missionary experiences and returned it to the Roman Empire or exported it further into Asia. Gardner's paper ends the first section of the book with the analysis of the "structure and the content" (p. 81) of the final ten chapters of $2 \mathrm{Ke}$, by uncovering literary duplicates as signs of an unfinished editorial process in the making of the Kephalaia (pp. 75-97),

The second section of the volume, "New Sources from the Chester Beatty Codex" (pp. 99-208), opens the examination to further crosscultural religious connections. In "Also Schrieb Zarathustra? Mani as Interpreter of the "Law of Zarades'” (pp. 101-35), Dilley examines three sayings initially attributed by 2 Ke to the "Law of Zarades," which, he claims, "reflect Iranian Zarathustra traditions" embraced by Manichaeans and interpreted in consonance with ancient Christian traditions. In "Iranian Epic in the Chester Beatty Kephalaia" (pp. 136-58), BeDuhn continues the line of inquiry opened by Dilley's piece, and inquires about the origins and the channels of circulation of the Hystaspes-Zoroaster material in the two volumes of the Manichaean Coptic Kephalaia. BeDuhn describes Mani as a religious leader who gathered perennial truths from various religious traditions, saving them from later misplaced hermeneutics, and complemented them with adopted local legends and tales, retold in Manichaean key. Gardner's “Mani's Last Days” (pp. 159-208) closes the second section of the book. Based on his readings of parts of $2 \mathrm{Ke}$, Gardner 
delineates a new possible chronology for Mani's last days, one that puts aside the highly polemical and anti-Manichaean fourth-century version of the Acts of Archelaus, without, however, discarding it completely.

The last part of the volume employs the particulars of philological and historical reconstruction to reevaluate the position of Manichaeism from the perspective of the history of religions. In "'Hell Exists, and We Have Seen the Place Where It Is': Rapture and Religious Competition in Sasanian Iran," Dilley expands on his opening piece by describing the ways in which Mani and the Zoroastrian priest Kartīr, employed similar "discourses on otherworldly realms" to engage in competition for patronage at the court of Sasanian Iran (pp. 211-46). Both the religious leaders sought the royal family's support for either the Manichaean electi or the Zoroastrian fire rituals. Dilley's helpful layers of contextualization identify Manichaean accounts of visionary experiences as essential to apostolic and missionary activities, to establishing authority, and to ritual and proselytism. Far from belonging to the realm of mere literary exercises, for Manichaeans and Zoroastrians equally, accounts of heaven and hell facilitated access to royal patronage in Sasanian Persia.

Over the past decade, scholars attempted to identify the configuration of the modern concept of 'religion' as a universal category within the scope of ancient religions. Their usual suspects were Judaism, Christianity, or its heresiological mutations. In "Mani and the Crystallization of the Concept of 'Religion' in Third-Century Iran," BeDuhn shifts the focus of this debate to the third-century formation of Manichaeism in Sasanian Persia (pp. 24775). BeDuhn argues that Mani's synthesis between the acknowledgment of past revelations of wisdom and the sole promotion of his own sapiential supersessionism further crystalized ethnical or cultural group self-definition into the concept of universal 'religion.' The conditions of third-century religious pluralism in Sasanian Iran allowed Mani to develop this notion of 
'religion' as a system of practices and texts that can be detached from its initial ethnic and cultural contexts, further exported, and adopted in foreign settings.

With Mani at the Court of the Persian Kings, we find ourselves aeons away from the distressing first sentence of BeDuhn's earlier major contribution to the history of Manichaeism: "We are in danger of losing the Manichaeans."3 A sophisticated exercise in anticipatory scholarship, Gardner, BeDuhn, and Dilley's chapters open new, exciting avenues of research, especially in understanding the complicated issue of the relations between Western and Eastern Manichaeism. The present volume feeds on previous scholarship of immense breath, yet it signals the beginning of a new stage in Manichaean scholarship, a stage that reassesses the Iranian pluralist cultural context of the nascent Manichaean religion. At the same time-and this is the only critical remark one could bring to Mani at the Court of the Persian Kingsthe formidable translatio capitulorum operated by the three scholars, that is, the shift of focus from the eastern Mediterranean world to Sasanian Persia, the place of Mani's activities, carries the risks of losing in translation the very Egyptian Manichaeans who produced, translated, circulated, and read the Coptic Codex of Chester Beatty Kephalaia.

Due to the provisional nature of this volume, Mani at the Court of the Persian Kings leaves its readers wanting for more: a work beyond the draft of the Coptic text itself; the critical edition of the Chester Beatty Kephalaia codex and an annotated translation of it; and further developments of the rich conclusions of this volume itself. As for its readership, while scholars of Manichaeism and Zoroastrianism will find it of immediate interest, students of late antique religious traditions will surely appreciate the rich

3 Jason BeDuhn, The Manichaean Body: In Discipline and Ritual (Baltimore: Johns Hopkins University Press, 2000), ix. 
methodological novelty of this volume. By providing their in-depth studies of 2 Ke years ahead of its critical edition, the authors advanced not only a model of 'open-platform' scholarship, one of an intense collaborative nature, but also provided an epistemological standard for investigating other religious traditions in contact and transformation.

\title{
EDUARD IRICINSCHI
}

\author{
Erlangen, Germany
}

